\title{
A Study Of The Capacity Of Nigerian Universities For Hosting Online Guidance And Counselling Services
}

\author{
Victor Adewale Adeniyi \\ Department of Educational Foundations and Counselling \\ Faculty of Education. Obafemi Awolowo University, Ile-Ife
}

\begin{abstract}
The study determined the availability and adequacy of facilities for Online Guidance and Counselling Services (OGCS) among Universities in Southwestern Nigeria and assessed the adequacy and competence of existing personnel for OGCS in the universities. The study adopted a survey research design. A sample of 108 staff members was selected using multi-stage sampling technique. The stratified sampling technique was used to select three out of the six states that make up Southwestern Nigeria. University staff Assessment of institutional Capacity for Online Guidance and Counselling Services (USAICOCS) A Checklist and Interview Guide (CAIG) and level of adequacy and competency of existing personnel for OGCS Questionnaire (LACPQ) were used to collect data for the study. The results showed that facilities for hosting OGCS such as internet, computer and electricity were available (more than $60 \%$ ). However, most of the other needed facilities such as online counselling platform application and counselling system data base recorded less than $50 \%$ of the minimum required. The availability of the facilities was therefore adjudged inadequate. The results also showed that the personnel for OGCS were grossly inadequate. None of them had ever handled OGCS equipment. The results further showed that the ICT section of each university had enough personnel that could set up the OGCS platform.
\end{abstract}

Key Words: Availability, Personnel-adequacy, Facilities, Universities, Online Guidance and Counselling

\section{INTRODUCTION}

Statistics from the Directorate of Students Affairs of two universities in Southwestern Nigeria as well as releases from the National Open University of Nigeria (NOUN) indicate that the population of university students is growing astronomically. (Tenebe, 2012 \& Adamu, 2017). As at $1^{\text {st }}$ January 1948, the University of Ibadan had 104 foundation students but as at the period of conducting this research, it has increased to 26,753. Also, the Obafemi Awolowo University formerly known as University of Ife, started with 244 foundation students in 1962. As at the beginning of 2015/2016 academic session, the university had 26,261 undergraduate students population. In addition to this, there were 4,000 staff members. The University had eighteen counsellors, eleven of which were saddled with academic, administrative and community service duties, apart from their primary counselling jobs (Adebowale, 2013). So also, NOUN which started with 30,400 students in 2002 had 180,000 students in 2012 and by 2017 , the figure had risen to 254,000 .

It is to be noted that these numerous students are faced with both individual and collective challenges that need to be addressed by the university authority through the services of counsellors. Failure to address students' challenges may negatively affect the students and staff members' wellbeing. Globally, communication is now made easy through the use of Information Communication Technology (ICT). The rate at which technology has become an integral part of all facets of modern day living is astounding. Virtually every human endeavour 
is being computerized. The computer has made life easier than the earlier years in the areas of encoding and decoding information in education, psychology, health and medical sciences, commerce, engineering, architecture, entertainment industry and other fields of life. It has virtually permeated all human endeavours to the extent that it is difficult to imagine contemporary life styles and ventures without computers, mobile phones and the internet (Ojo, 2012). Counselling services as well require the use of Information and Communication Technology (ICT) in the Universities because of the advantages inherent in it.

Information Communication Technology has been playing an ever-increasing role in the social lives of young people all over the world. The youths have been quick to immerse themselves in technology with most of them using the internet to communicate (Bahr \& Pendergast, 2007). Young people, as posited by Campbell (2005), treat the mobile phones as an essential and indispensible necessity of life. They are said to be born into it. They often prefer to use asynchronous chat to communicate with their friends.

Technology and the internet are familiar resources for young people. (Bahr \& Pendergast, 2007).This has been shown by the increase in various forms of websites that provide therapeutic information for them. The therapeutic information presented often takes the form of a. frequently asked questions, b. facts sheets, and c. suggested links (Campbell \& Glasheen, 2012). It would seem reasonable therefore to provide online counselling for young people using the familiar technological devices and the internet which are not new to them and they are already conversant with.

Yusuf and Balogun (2011) reported that majority of student-teachers in the university had positive attitude toward the use of ICT. They are competent in the use of some of the basic ICT tools. Overall, they discovered that no significant difference was established between male and female student-teachers' attitudes and the use of ICT. The implication is that the studentteachers had the necessary knowhow wherewith the competence in the full integration of ICT could be achieved. This underscores the need to further improve the ICT contents of teacher education programs to further enhance the production of more ICT skilled personnel in developing nations.

Umoh (2004) posited that in nearly all the societies of the world, people have always turn to other people for help whenever they encountered personal problems or challenges they could not solve single-handedly. Young people have always turned to adults or other significant people in the community to help them on issues bordering them, especially the ones that are related to career choices, emotional problems and even spiritual needs. Many of them resort to dealing with difficult problems by talking to their friends, families, neighbours, priests or sooth sayers. They would have been better counselled if they had professional counsellors to turn to.

Traditional (face-to-face) guidance and counselling was introduced into schools from primary to tertiary levels of educational institutions in compliance with the directives of the Federal Republic of Nigeria (FRN, 1981) in the National Policy on Education (NPE). The goal is to help the learner understand him or herself and make correct choices from innumerable alternatives. To achieve this ultimate goal, counsellors are trained to help the individual make appropriate choices; identify his/her strengths and potentials for coping with challenges. The choice of the alternatives is however made by the individual themselves (Okobiah \& Okorodudu, 2004). 


\section{Issues for Online Counselling}

Adebowale and Popoola (2011) posited that in spite of the establishment of guidance and counselling services in Nigerian schools, many students still live with concerns and challenges they find difficult to discuss face-to-face with counsellors probably because of the fear of reprisals, being stigmatised or of becoming a laughing stock. Adebowale (2013) corroborated the fact that guidance and counselling services are expected to provide the students the support needed to maintain sanity and resolve emotional challenges. However, the counsellors employed for the services in the universities have not been able to reach out to most of the clients in need of support services because of the unmanageable population of students in the universities. This could be attributed to the low counsellors-clients ratio among other reasons. Coincidentally, the student population in the university had been on the rise in terms of not only the numbers, but also in terms of complexity of challenges and diversity of cultures. Some of the universities are even noted for not denying admission to students on the basis of age or any other consideration apart from the academic ability of the applicant (Adebowale, 2013) This makes their counselling needs to be varied and diverse.

Studies, (Arijesuyo, 2013 \& Adebowale, 2013) have shown that available counsellors are not enough for the delivery of the conventional guidance and counselling services to staff and students in the universities (Adebowale 2013). In addition to this, some of the clients may not want to come into the open, but rather prefer where they can enjoy secrecy, end to end encryption of their messages and anonymity and at the same time still get their problems solved (University of Zurich 2013, Vosler \& Hanley 2010). This means that the face-to-face counselling approach may not possibly be able to meet the counselling needs of all the teaming population of students and staff in the universities. In an attempt to get the counselling problems solved, in spite of all these lapses, online counselling services through the use of ICT become highly imperious and expedient.

There seems to be no university yet in Nigeria that is funding, utilizing and maintaining an organized online guidance and counselling platform for counselling students that are admitted into their institutions yearly. Wherever it is claimed to be in existence, the effectiveness of the services needs to be verified. Although the universities might have access to the internet facilities, which is one of the necessary requirements to hosting online counselling services, it is not being utilized for online guidance and counselling services. Rather, it was observed that the universities only use their internet facilities for admission processes, registration of students, students' online payments, results checking and request for accommodation among others. There is no gainsaying that this is not what online counselling entails. This exercise the universities engaged in could just be seen as mere modern administrative routine that is put in place to ease some administrative concerns.

According to Mallen, Michael, David and Vogel (2005), online counselling is the provision of professional mental health counselling services through the use of the internet. Online services, according to them are typically offered through the email, real time chat and videoconferencing. Adebowale (2013) discovered that online counselling is viable in Nigeria. In view of the fact that most universities in Nigeria have made their impact on the internet, coupled with the fact that most Nigerian students are familiar with the terrain of computers and internet utilization, it may therefore be logical to say that the introduction of online guidance and counselling services into Nigerian universities would not be a herculean task to be achieved. 


\section{What the Setting up of Online Guidance and Counselling Platform Entails}

What goes into setting up of online guidance and counselling transcends the availability of the internet. There are other things like men, money, materials and management that are involved. The personnel to be involved is not only made up of trained, certified, seasoned and practicing online counsellors, it is also inclusive of computer scientists, computer engineers, computer programmers, electrical engineers, software designers and even facility managers such as cleaners to mention but a few.

If the online counselling process is duly in place, clients should be able to call on counsellors whether by day or night. The moment they are able to chat with the professional counsellors online, and counselling intervention is given, it is envisaged that both the counsellor and the counsellee will be able to work out solution. It must be pointed out here however that there are some logistics that must be put in place so that things could work out favourably. For instance, there is the need for online counsellors to be on duty every hour of the day and even night. This might therefore necessitate the need for more personnel who will be working on rotational (shifting) duties. Hence, there is need to recruit more counsellors, train and re-train the existing counsellors.

It has been discovered that the teaming population of the staff and students' population in Nigerian universities do not give room for effective face to face counselling due to high clientcounsellor ratio. Studies (Adebowale, 2013; University of Zurich, 2013; Vosler \& Hanley,2010) have shown that not all students are willing to come for face-to-face counselling for reasons ranging from clients' academic and administrative workload, culture of silence existing in Nigeria, shyness as well as fear of stigmatization, among others. Thus, online guidance and counselling services could fill the gaps in the traditional face-to-face counselling practice.

INSTITUTIONAL CAPACITY: To be able to set up online counselling outfit effectively, it is necessary to determine the capacity of the universities for hosting online counselling services in their domains. For this study, the term 'institutional capacity' refers to the capability of the universities to host online counselling services. Capacity is defined as the ability, capability or fitness to do something; or competence to perform some act. By inference therefore the term "Institutional capacity" refers to the ability, capability and fitness of the universities as institutions of higher learning to provide, implement, finance and maintain online guidance and counselling services.

The foundation of online guidance and counselling services is the conventional Face-To-Face (FTF) counselling. Research has however pointed out that with the current globalization, people tend to travel far and near for socio-economic reasons among others. Such student or member of staff of such university, who had travelled, may intend to contact his/her counsellor while outside the university campus. With the internet access nowadays, the counsellees and the counsellors can link up.

Several researchers have worked on online counselling and have examined several aspects of it. For instance, Suler (1998) wrote on online psychotherapy and counselling. Suler (2001) also wrote on online disinhibition effects, which look as alien and impracticable theory. Also Adebowale, Popoola, Obisakin and Aluede (2012) studied the emerging role of online counselling in Nigerian universities using Obafemi Awolowo University as a point of reference. The viability of online counselling services was studied in one of the southwestern universities by Adebowale (2013). The study showed that the facilities needed for online counselling were not wholly available in the university. Sharma (2011) was of the opinion that there are numerous ways to transform the digital divide into digital opportunities for as long as the 
financial implication could be borne by the stake holders. In Nigeria, the potential advantages of digitalization have not been given room for actualization. It is high time Nigeria moved with the tide of times and participated in the globalization agenda. The whole world is fast becoming a unit through the availability and use of the internet. Joining the world internet users for online counselling services will surely enable counsellors to reach the "unreachables." It is high time Nigeria joined the users of the internet to deliver counselling assistance to numerous clients who would prefer anonymity and would still get their problems solved.

\section{Statement of Research Problem}

Many Nigerian universities have established conventional guidance and counselling services to help students overcome their psycho-social and academic challenges. The efficiency and effectiveness of the services are, however, hindered by several factors among which are shortage of personnel and unmanageable student population.

Globally, there is a consensus that online counselling is a viable alternative platform to mitigate the limitations of conventional counselling. However, as desirable as online counselling services may be, it is not certain that Nigerian universities have enough human and material resources required for its implementation. There had also been little attempt to investigate on whether or not Nigerian universities are capable of hosting online guidance and counselling which is currently in vogue globally. According to Adebowale (2014), in spite of the varieties of applications to which ICT has been deployed, counselling services are not yet available through ICT. He posited that if counselling is allowed to share in the ICT capabilities, many counselling needs of students are likely to be met. Meanwhile, the attempt to establish online counselling services in Nigerian universities must begin with an empirical investigation of the capacity of the universities for its implementation; hence this study.

The objectives of the study are to:

\section{OBJECTIVES OF THE STUDY}

a. determine the availability of facilities for Online Guidance and Counselling Services in the universities;

b. determine the adequacy and competence of existing personnel for Online Guidance and Counselling Services in the institutions;

\section{RESEARCH QUESTIONS}

1) What is the capacity of the Universities for Online Guidance and Counselling Services in terms of facilities?

2) What is the degree of adequacy and competence of available personnel in the Universities to handle online equipment?

\section{METHOD}

A sample of 108 staff members was selected using multi-stage sampling technique. On the first stage, the stratified sampling technique was used to select three out of the six states that make up Southwestern Nigeria. Geographical contiguity and socio-political background were used as basis for stratification.

In each of the three states, three universities were selected using stratified sampling technique with university ownership as basis for stratification. This yielded nine universities for the study, that is, three each of federal, state and private universities. To gather responses from the staff, officers in the Guidance and Counselling service delivery centres, and the Computer Science and Engineering Departments were purposively selected as they were directly involved with the usage and installation of online counselling platform respectively. These staff 
members were contacted for responses to the questionnaire and the interviews conducted. This summed up to a total of 108 staff members in the universities. The selected participants were members of staff, whose work were related or having something to do with guidance and counselling services delivery and platform installation.

Two research instruments were constructed to measure the level of patronage, attitudes towards online counselling as well as availability, adequacy and competence of both human and material facilities for the establishment of online guidance and counselling service. Each of these instruments is described below:

(i) University Staff Assessment of Institutional Capacity for Online Counselling Services (USAICOCS) was self-constructed to collect data from members of staff of the universities especially from guidance and counselling service delivery center, computer engineering and computer science departments of each university, to elicit information on the availability and adequacy of listed items in the checklist. The first section is a 21 item list of facilities required for hosting online counselling. The staff is to identify the ones they are aware is existing in their institutions. It has three options from which the respondents can select one from Available, not available and I don't know. Available was scored 1 while Not available and Don't know were scored 0 . This was done to collate staff awareness of availability of needful facilities in the universities. Also section (1) has 24 items designed to measure the adequacy of the needful facilities in each of the universities. It has three options from which the respondents can select one from Available, not available and I don't know. Adequate was scored 1 while Not adequate and Don't know were scored 0 . This was done to collate staff awareness of adequacy of needful facilities in the universities. Sections 2 and 3 investigated adequacy and competence of personnel of counselling and ICT centers respectively.

(ii) Checklist and Interview Guide" (CAIG) was developed and used to collate information through interview that was conducted to the Computer Engineers, Directors, H.O.Ds, Fieldworkers and major stake holders in guidance and counselling and computer sections of the universities to probe further the availability and adequacy of needful facilities other than what was supplied in the questionnaire for the establishment of online guidance and counselling platform. The instruments were validated and modifications were made where necessary.

The research instruments were administered by the researcher in person with the help of two research assistants who were trained by the researcher. Required permission to administer the questionnaire was sought and obtained from the authorities of the participating institutions. All respondents were assured of the confidentiality of the information supplied by them. Technical terms in the questionnaire were explained to respondents. A total of 108 copies of the staff questionnaire (USAICOCS) were filled and returned by the staff respondents. The data collection was adjudged highly successful because of the percentage $(100 \%)$ of the respondents that returned the questionnaire that was administered on them. Data collection lasted a period of twelve weeks. 


\section{RESULTS}

Research Question 1: What is the capacity of the universities in Southwestern Nigeria for online guidance and counselling services in terms of facilities?

To answer this research question, the responses of the selected university staff, (academic and non-academic) to items in the questionnaire titled "University Staff's Assessment of Institutional Capacity for Online Guidance and Counselling Services (USAICOCS) questionnaire were scored. One (1) mark was allotted for each of the available facilities and zero (0) mark for the facility that was not available. The cumulative score of each university on all the facilities was determined and expressed as a percentage of the total obtainable score for facilities. This was used to arrive at a decision on the capacity of the universities for online guidance and counselling services in terms of facilities. Using this approach, universities with cumulative scores of $60 \%$ and above were classified as having "Adequate Capacity" for facilities. Those with scores of $41 \%$ and $59 \%$ were classified as having "Fairly Adequate" while those with 1\% and $40 \%$ were classified as "Not Adequate". The results of this analysis are presented in Table 1 
Table 1: Universities' Capacities for Online Guidance and Counselling Services Facilities. ONLINE COUNSELLING FACILITIES

\begin{tabular}{|c|c|c|c|c|c|c|c|c|c|}
\hline \multirow[t]{2}{*}{ ONLINE COUNSELLING FACILITIES } & \multicolumn{9}{|c|}{ CUMULATIVE FACILITY SCORES BY INSTITUTIONS } \\
\hline & $\begin{array}{r}\text { ABUA } \\
\text { D }\end{array}$ & $\begin{array}{r}\text { BABC } \\
\text { OCK }\end{array}$ & EKSU & $\begin{array}{l}\text { FUN } \\
\text { AAB }\end{array}$ & $\begin{array}{r}\text { FUO } \\
\text { YE }\end{array}$ & OAU & OOU & RUN & $\begin{array}{r}\text { UNIOS } \\
\text { UN }\end{array}$ \\
\hline Internet facilities & $\begin{array}{r}11 \\
100 \%\end{array}$ & $\begin{array}{r}12 \\
100 \%\end{array}$ & $\begin{array}{r}12 \\
100 \%\end{array}$ & $\begin{array}{r}12 \\
100 \%\end{array}$ & $\begin{array}{r}12 \\
100 \\
\%\end{array}$ & $\begin{array}{r}12 \\
100 \%\end{array}$ & $\begin{array}{r}12 \\
100 \%\end{array}$ & $\begin{array}{r}11 \\
100 \%\end{array}$ & $\begin{array}{r}12 \\
100 \%\end{array}$ \\
\hline Counselling laboratory & $\begin{array}{r}7 \\
63.6 \% \\
\end{array}$ & $\begin{array}{r}5 \\
41.6 \% \\
\end{array}$ & $\begin{array}{r}0 \\
0 \% \\
\end{array}$ & $\begin{array}{r}3 \\
25 \% \\
\end{array}$ & $\begin{array}{r}1 \\
8.3 \% \\
\end{array}$ & $\begin{array}{r}1 \\
8.3 \% \\
\end{array}$ & $\begin{array}{r}0 \\
0 \% \\
\end{array}$ & $\begin{array}{r}0 \\
0 \% \\
\end{array}$ & $\begin{array}{r}7 \\
58.3 \% \\
\end{array}$ \\
\hline $\begin{array}{l}\text { Exclusively separated and kitted room/office for } \\
\text { online counselling platform }\end{array}$ & $\begin{array}{r}3 \\
27.3 \%\end{array}$ & $\begin{array}{r}4 \\
33.3 \%\end{array}$ & $\begin{array}{r}0 \\
0 \%\end{array}$ & $\begin{array}{r}5 \\
41.6 \\
\%\end{array}$ & $\begin{array}{r}0 \\
0 \%\end{array}$ & $\begin{array}{r}0 \\
0 \%\end{array}$ & $\begin{array}{r}3 \\
25 \%\end{array}$ & $\begin{array}{r}2 \\
18.2 \%\end{array}$ & $\begin{array}{r}3 \\
25 \%\end{array}$ \\
\hline $\begin{array}{l}\text { Electronic library where the students and staff } \\
\text { can come and use the computer for counselling }\end{array}$ & $\begin{array}{r}4 \\
36.4 \%\end{array}$ & $\begin{array}{r}4 \\
33.3 \%\end{array}$ & $\begin{array}{r}2 \\
16.7 \%\end{array}$ & $\begin{array}{r}3 \\
25 \%\end{array}$ & $\begin{array}{r}1 \\
8.3 \%\end{array}$ & $\begin{array}{r}2 \\
16.7 \%\end{array}$ & $\begin{array}{r}2 \\
16.7 \\
\%\end{array}$ & $\begin{array}{r}1 \\
9.1 \%\end{array}$ & $\begin{array}{r}6 \\
50 \%\end{array}$ \\
\hline Computer and other computer hardware & $\begin{array}{r}6 \\
54.5 \%\end{array}$ & $\begin{array}{r}6 \\
50 \%\end{array}$ & $\begin{array}{r}3 \\
25 \%\end{array}$ & $\begin{array}{r}9 \\
75 \%\end{array}$ & $\begin{array}{r}5 \\
41.6 \\
\%\end{array}$ & $\begin{array}{r}9 \\
75 \%\end{array}$ & $\begin{array}{r}4 \\
33.3 \\
\%\end{array}$ & $\begin{array}{r}9 \\
81.8 \%\end{array}$ & $\begin{array}{r}7 \\
58.3 \%\end{array}$ \\
\hline Palm-top computer/handset. & $\begin{array}{r}7 \\
63.6 \%\end{array}$ & $\begin{array}{r}7 \\
58.3 \%\end{array}$ & $\begin{array}{r}1 \\
8.3 \%\end{array}$ & $\begin{array}{r}7 \\
58.3 \\
\% \\
\end{array}$ & $\begin{array}{r}4 \\
33.3 \\
\% \\
\end{array}$ & $\begin{array}{r}8 \\
66.7 \%\end{array}$ & $\begin{array}{r}1 \\
8.3 \%\end{array}$ & $\begin{array}{r}10 \\
90.9 \%\end{array}$ & $\begin{array}{r}7 \\
58.3 \%\end{array}$ \\
\hline Online Counselling platform application & $\begin{array}{r}2 \\
18.2 \% \\
\end{array}$ & $\begin{array}{r}2 \\
16.7 \% \\
\end{array}$ & $\begin{array}{r}0 \\
0 \% \\
\end{array}$ & $\begin{array}{r}1 \\
8.3 \% \\
\end{array}$ & $\begin{array}{r}0 \\
0 \% \\
\end{array}$ & $\begin{array}{r}1 \\
8.3 \% \\
\end{array}$ & $\begin{array}{r}0 \\
0 \% \\
\end{array}$ & $\begin{array}{r}1 \\
9.1 \% \\
\end{array}$ & $\begin{array}{r}0 \\
0 \% \\
\end{array}$ \\
\hline Personnel with good working condition. & $\begin{array}{r}11 \\
100 \%\end{array}$ & $\begin{array}{r}11 \\
91.7 \%\end{array}$ & $\begin{array}{r}10 \\
91.7 \%\end{array}$ & $\begin{array}{r}12 \\
100 \%\end{array}$ & $\begin{array}{r}9 \\
75 \%\end{array}$ & $\begin{array}{r}7 \\
58.3 \%\end{array}$ & $\begin{array}{r}10 \\
83.3 \\
\%\end{array}$ & $\begin{array}{r}11 \\
100 \%\end{array}$ & $\begin{array}{r}11 \\
91.7 \%\end{array}$ \\
\hline $\begin{array}{l}\text { Good computer programming and engineering } \\
\text { work that will ensure encryption. }\end{array}$ & $\begin{array}{r}6 \\
54.5 \%\end{array}$ & $\begin{array}{r}9 \\
75 \%\end{array}$ & $\begin{array}{r}6 \\
50 \%\end{array}$ & $\begin{array}{r}9 \\
75 \%\end{array}$ & $\begin{array}{r}4 \\
33.3 \\
\% \\
\end{array}$ & $\begin{array}{r}3 \\
25 \%\end{array}$ & $\begin{array}{r}8 \\
66.7 \\
\% \\
\end{array}$ & $\begin{array}{r}3 \\
27.3 \%\end{array}$ & $\begin{array}{r}4 \\
33.3 \%\end{array}$ \\
\hline $\begin{array}{l}\text { Enough computer hardware and peripherals. } \\
\text { Lighting facilities, micro-films/memory cards. }\end{array}$ & $\begin{array}{r}5 \\
45.5 \%\end{array}$ & $\begin{array}{r}5 \\
41.6 \%\end{array}$ & $\begin{array}{r}5 \\
41.6 \%\end{array}$ & $\begin{array}{r}6 \\
50 \%\end{array}$ & $\begin{array}{r}4 \\
33.3 \\
\%\end{array}$ & $\begin{array}{r}6 \\
50 \%\end{array}$ & $\begin{array}{r}4 \\
33.3 \\
\%\end{array}$ & $\begin{array}{r}8 \\
72.7 \%\end{array}$ & $\begin{array}{r}5 \\
41.6 \%\end{array}$ \\
\hline Electricity (power supply), (Solar Power). & $\begin{array}{r}11 \\
100 \%\end{array}$ & $\begin{array}{r}10 \\
83.3 \%\end{array}$ & $\begin{array}{r}10 \\
83.3 \%\end{array}$ & $\begin{array}{r}12 \\
100 \%\end{array}$ & $\begin{array}{r}11 \\
91.7 \\
\% \\
\end{array}$ & $\begin{array}{r}12 \\
100 \%\end{array}$ & $\begin{array}{r}12 \\
100 \%\end{array}$ & $\begin{array}{r}1 \\
9.1 \%\end{array}$ & $\begin{array}{r}12 \\
100 \%\end{array}$ \\
\hline Automatic voltage regulator (AVR or stabilizer), & $\begin{array}{r}9 \\
81.8 \%\end{array}$ & $\begin{array}{r}12 \\
100 \%\end{array}$ & $\begin{array}{r}11 \\
91.7 \%\end{array}$ & $\begin{array}{r}12 \\
100 \%\end{array}$ & $\begin{array}{r}8 \\
66.7 \\
\%\end{array}$ & $\begin{array}{r}10 \\
83.3 \%\end{array}$ & $\begin{array}{r}11 \\
91.7 \%\end{array}$ & $\begin{array}{r}9 \\
81.8 \%\end{array}$ & $\begin{array}{r}11 \\
91.7 \%\end{array}$ \\
\hline Standby power generating set. & $\begin{array}{r}5 \\
45.5 \%\end{array}$ & $\begin{array}{r}10 \\
83.3 \%\end{array}$ & $\begin{array}{r}6 \\
50 \%\end{array}$ & $\begin{array}{r}9 \\
75 \%\end{array}$ & $\begin{array}{r}4 \\
33.3 \\
\% \\
\end{array}$ & $\begin{array}{r}8 \\
66.7 \%\end{array}$ & $\begin{array}{r}7 \\
58.3 \\
\% \\
\end{array}$ & $\begin{array}{r}8 \\
72.7 \%\end{array}$ & $\begin{array}{r}4 \\
33.3 \%\end{array}$ \\
\hline $\begin{array}{l}\text { Counselling data base usable for counselling } \\
\text { systems. }\end{array}$ & $\begin{array}{r}1 \\
9.1 \%\end{array}$ & $\begin{array}{r}2 \\
16.7 \%\end{array}$ & $\begin{array}{r}1 \\
8.3 \%\end{array}$ & $\begin{array}{r}1 \\
8.3 \%\end{array}$ & $\begin{array}{r}1 \\
8.3 \%\end{array}$ & $\begin{array}{r}4 \\
33.3 \%\end{array}$ & $\begin{array}{r}4 \\
33.3 \\
\%\end{array}$ & $\begin{array}{r}1 \\
9.1 \%\end{array}$ & $\begin{array}{r}2 \\
16.7 \%\end{array}$ \\
\hline Electronic-books (e-books) & $\begin{array}{r}4 \\
36.4 \%\end{array}$ & $\begin{array}{r}4 \\
33.3 \%\end{array}$ & $\begin{array}{r}4 \\
33.3 \%\end{array}$ & $\begin{array}{r}8 \\
66.7 \\
\% \\
\end{array}$ & $\begin{array}{r}6 \\
50 \%\end{array}$ & $\begin{array}{r}8 \\
66.7 \%\end{array}$ & $\begin{array}{r}5 \\
41.6 \\
\% \\
\end{array}$ & $\begin{array}{r}5 \\
45.5 \%\end{array}$ & $\begin{array}{r}8 \\
66.7 \%\end{array}$ \\
\hline $\begin{array}{l}\text { Audio recorder facility (Audio-visual recorder in } \\
\text { case the institution is using Skype). }\end{array}$ & $\begin{array}{r}3 \\
27.3 \% \\
\end{array}$ & $\begin{array}{r}4 \\
33.3 \% \\
\end{array}$ & $\begin{array}{r}3 \\
25 \% \\
\end{array}$ & $\begin{array}{r}9 \\
75 \% \\
\end{array}$ & $\begin{array}{r}1 \\
8.3 \% \\
\end{array}$ & $\begin{array}{r}8 \\
66.7 \% \\
\end{array}$ & $\begin{array}{r}3 \\
25 \% \\
\end{array}$ & $\begin{array}{r}4 \\
36.4 \% \\
\end{array}$ & $\begin{array}{r}7 \\
58.3 \% \\
\end{array}$ \\
\hline $\begin{array}{l}\text { Application software to be designed by computer } \\
\text { programmers and analysts. }\end{array}$ & $\begin{array}{r}6 \\
54.5 \%\end{array}$ & $\begin{array}{r}4 \\
33.3 \%\end{array}$ & $\begin{array}{r}4 \\
33.3 \%\end{array}$ & $\begin{array}{r}7 \\
58.3 \\
\% \\
\end{array}$ & $\begin{array}{r}2 \\
16.7 \\
\% \\
\end{array}$ & $\begin{array}{r}0 \\
0 \%\end{array}$ & $\begin{array}{r}5 \\
41.6 \\
\% \\
\end{array}$ & $\begin{array}{r}4 \\
36.4 \%\end{array}$ & $\begin{array}{r}2 \\
16.7 \%\end{array}$ \\
\hline C. D. Rom. & $\begin{array}{r}11 \\
100 \% \\
\end{array}$ & $\begin{array}{r}10 \\
83.3 \% \\
\end{array}$ & $\begin{array}{r}12 \\
100 \% \\
\end{array}$ & $\begin{array}{r}12 \\
100 \% \\
\end{array}$ & $\begin{array}{r}12 \\
100 \% \\
\end{array}$ & $\begin{array}{r}10 \\
83.3 \% \\
\end{array}$ & $\begin{array}{r}11 \\
91.7 \% \\
\end{array}$ & $\begin{array}{r}11 \\
100 \% \\
\end{array}$ & $\begin{array}{r}11 \\
91.7 \% \\
\end{array}$ \\
\hline $\begin{array}{l}\text { Training and retraining facilities for personnel } \\
\text { (especially Face-to-Face trained counsellors). }\end{array}$ & $\begin{array}{r}6 \\
54.5 \%\end{array}$ & $\begin{array}{r}6 \\
50 \%\end{array}$ & $\begin{array}{r}8 \\
66.7 \%\end{array}$ & $\begin{array}{r}11 \\
91.7 \\
\% \\
\end{array}$ & $\begin{array}{r}5 \\
41.6 \\
\% \\
\end{array}$ & $\begin{array}{r}4 \\
33.3 \%\end{array}$ & $\begin{array}{r}3 \\
25 \%\end{array}$ & $\begin{array}{r}6 \\
54.5 \%\end{array}$ & $\begin{array}{r}5 \\
41.6 \%\end{array}$ \\
\hline $\begin{array}{l}\text { Steady online advertisement for the Access Apps } \\
\text { for online counselling on the university porter } \\
\text { and on every registered student's e-page. }\end{array}$ & $\begin{array}{r}11 \\
100 \%\end{array}$ & $\begin{array}{r}10 \\
83.3 \%\end{array}$ & $\begin{array}{r}11 \\
91.7 \%\end{array}$ & $\begin{array}{r}9 \\
75 \%\end{array}$ & $\begin{array}{r}11 \\
91.7 \\
\% \\
\end{array}$ & $\begin{array}{r}11 \\
91.7 \%\end{array}$ & $\begin{array}{r}11 \\
91.7 \%\end{array}$ & $\begin{array}{r}11 \\
100 \%\end{array}$ & $\begin{array}{r}12 \\
100 \%\end{array}$ \\
\hline Officed Air conditioners. & $\begin{array}{r}11 \\
100 \%\end{array}$ & $\begin{array}{r}12 \\
100 \%\end{array}$ & $\begin{array}{r}12 \\
! 00 \%\end{array}$ & $\begin{array}{r}12 \\
100 \%\end{array}$ & $\begin{array}{r}11 \\
91.7 \\
\%\end{array}$ & $\begin{array}{r}10 \\
83.3 \%\end{array}$ & $\begin{array}{r}12 \\
100 \%\end{array}$ & $\begin{array}{r}11 \\
100 \%\end{array}$ & $\begin{array}{r}10 \\
83.3 \%\end{array}$ \\
\hline CUMULATIVE MAXIMUM OBTAINABLE SCORES & 231 & 252 & 252 & 252 & 252 & 252 & 252 & 231 & 252 \\
\hline $\begin{array}{l}\text { CUMULATIVE SCORE OBTAINED ON ALL } \\
\text { FACILITIES }\end{array}$ & $\begin{array}{r}134 \\
58 \%\end{array}$ & $\begin{array}{r}149 \\
59 \%\end{array}$ & $\begin{array}{r}123 \\
48 \%\end{array}$ & $\begin{array}{r}169 \\
67 \%\end{array}$ & $\begin{array}{r}112 \\
44.4 \\
\%\end{array}$ & $\begin{array}{r}134 \\
53 \%\end{array}$ & $\begin{array}{r}130 \\
51.6 \%\end{array}$ & $\begin{array}{r}127 \\
55 \%\end{array}$ & $\begin{array}{r}156 \\
62 \%\end{array}$ \\
\hline
\end{tabular}




\begin{tabular}{|l|r|r|r|r|r|r|r|r|r|}
\hline DECISION ON CAPACITY & A. & A. & F.A. & A. & F.A. & .A. & .A. & .A. & A. \\
\hline
\end{tabular}

Note: $\mathrm{A}=$ Adequate, F. A. = Fairly Adequate

\section{Universities}

1. ABUAD - Afe Babalola University, Ado-Ekiti, Ekiti State.

2. BABCOCK - Babcock University Ilishan Remo Ogun State.

3. EKSU - Ekiti State University Ado-Ekiti, Ekiti State.

4. FUNAAB - Federal University of Agriculture, Abeokuta Ogun State.

5. FUOYE - Federal University Oye Ekiti Ekiti State.

6. O.A.U - Obafemi Awolowo University, Ile-Ife Osun State.

7. O.O.U - Olabisi Onabanjo University Ago-Iwoye Ogun State.

8. R.U.N - Redeemers University, Ede Osun State.

9. UNIOSUN - Osun State University, Osogbo, Osun State.

The results as presented in Table 1 show that the universities' capacity in terms of facility is high with regard to facilities such as Internet, Electricity power supply, C. D. Rom, and office air conditioners. This is because each university's cumulative score on the identified facilities are very close to maximum obtainable cumulative score. Thus, the facilities are interpreted to be available and adequate. However, the capacity of the universities for online guidance and counselling services in terms of facilities such as; electronic library, counselling database usable for counselling services, electronic-books, and audio recorder facility is low and may be said not to be adequately available in the universities with cumulative scores that fall below $50 \%$ of the maximum obtainable cumulative scores.

Research Question 2: What is the degree of adequacy and competence of available personnel in the universities to handle equipment for online counselling services?

To answer this research question, an instrument titled Adequacy and Competence of Personnel for Online Counselling (ACPOCS) was administered to all the Heads of Department/Directors of Counselling Services and Directors of Information Communication and Technology units in each of the selected universities. Their responses were collated and inferences were drawn from the responses. The results as presented in Tables 2 and 3 show the data on the adequacy of counsellors for online guidance and counselling services.

Table 2: Adequacy of Counsellors to Manage Online Guidance and Counselling Services.

\begin{tabular}{|l|c|c|c|c|}
\hline \multirow{2}{*}{ INSTITU-TIONS } & \multicolumn{3}{|c|}{ ADEQUACY } \\
\cline { 2 - 5 } & $\begin{array}{c}\text { Number of } \\
\text { Counsellors on } \\
\text { Ground }\end{array}$ & $\begin{array}{c}\text { Number of Counsellors } \\
\text { Required }\end{array}$ & $\begin{array}{c}\text { Percentage of } \\
\text { Counsellors } \\
\text { Existing }\end{array}$ & Remark \\
\hline OAU & 6 & 30 & $20 \%$ & Not Adequate \\
\hline FUNNAB & 4 & 20 & $20 \%$ & Not Adequate \\
\hline FUOYE & 1 & 5 & $20 \%$ & Not Adequate \\
\hline OOU & 6 & 18 & $33.3 \%$ & Not Adequate \\
\hline UNIOSUN & 3 & 20 & $15 \%$ & Not Adequate \\
\hline EKSU & 4 & 20 & $20 \%$ & Not Adequate \\
\hline ABUAD & 2 & 20 & $10 \%$ & Not Adequate \\
\hline BABCOCK & 5 & 15 & $33.3 \%$ & Not Available \\
\hline RUN & 1 & 3 & $33.3 \%$ & Not Adequate \\
\hline
\end{tabular}

In determining the adequacy of the counsellors for each university, a university with a score of $60 \%$ and above was rated as adequate, those with a score of $41 \%$ to $59 \%$ were rated Fairly 
Adequate while those that rated $1 \%$ to $40 \%$ were rated Not Adequate. Results as presented in Table 2 show that none of the selected universities had adequate number of required personnel for the implementation of online counselling. It is therefore concluded that in terms of personnel, none of the universities has adequate capacity for online counselling services.

Table 3: Competence of Universities' Personnel to Manage Online Counselling Platform

\begin{tabular}{|c|c|c|c|}
\hline \multirow{2}{*}{$\begin{array}{l}\text { INSTITU- } \\
\text { TIONS }\end{array}$} & \multicolumn{3}{|c|}{ COMPETENCE } \\
\hline & Qualification & $\begin{array}{c}\text { Year of } \\
\text { experience in the } \\
\text { university }\end{array}$ & $\begin{array}{c}\text { Number that had been managing } \\
\text { online counselling platform }\end{array}$ \\
\hline OAU & $\begin{array}{l}\text { B.A. } \\
\text { M.A./ M.Ed./ MPhil (4) } \\
\text { Counselling }\end{array}$ & 5-10 Years & Nil \\
\hline FUNNAB & $\begin{array}{l}\text { M.A./M.Ed./M.Phil } \\
\text { Counselling }\end{array}$ & 5-12 Years & Nil \\
\hline FUOYE & $\begin{array}{l}\text { M.A. /M.Ed./MPhil } \\
\text { counselling }\end{array}$ & 2 Years & Nil \\
\hline OOU & $\begin{array}{l}\text { M.A./M.Ed/M.Phil } \\
\text { Counselling }\end{array}$ & 5-7 Years & Nil \\
\hline UNIOSUN & $\begin{array}{ll}\text { B.A. Counselling } & (2) \\
\text { M.A./M.Ed./.MPhil } & (2) \\
\end{array}$ & 5-10 Years & Nil \\
\hline EKSU & B.A. Counselling & 5-10 Years & Nil \\
\hline ABUAD & $\begin{array}{ll}\text { B.A. } & (1) \\
\text { Ph. D Counselling } & (1) \\
\end{array}$ & 3 Years & Nil \\
\hline BABCOCK & $\begin{array}{cc}\text { M.A./M.Ed./MPhil } & (4) \\
\text { Ph. D Counselling } & (1) \\
\end{array}$ & 5-10 Years & Nil \\
\hline RUN & $\begin{array}{l}\text { Degree outside Guidance \& } \\
\text { Counselling }\end{array}$ & Not Specified & Nil \\
\hline
\end{tabular}

(N) - Number of Personnel available with the degree.

Table 3 shows that even though most of the existing personnel in the universities were professionally qualified and have some years of experience as workers in the university, none of them had ever managed an online counselling platform. Thus, it is concluded that the existing counselling personnel in the universities were not competent to handle online guidance and counselling services unless they are given training.

Further data were collected from the ICT Units of the institutions to ascertain the adequacy and competence of ICT personnel to handle the installation and maintenance of online counselling equipment in each of the selected universities. For each University, the number of required personnel $(\mathrm{R})$ was determined as well as the number available personnel $(\mathrm{A})$. The results are presented in Table 4. 
Table 4: Adequacy and competence of ICT personnel for Online Guidance and Counselling Services in the Universities.

\begin{tabular}{|c|c|c|c|c|c|c|c|c|c|c|c|c|c|c|c|c|}
\hline \multirow{3}{*}{$\begin{array}{l}\text { INSTIT } \\
\text { UTIONS }\end{array}$} & \multicolumn{16}{|c|}{ Available ICT Personnel to Start Online Guidance and Counselling Platform } \\
\hline & \multicolumn{2}{|c|}{$\begin{array}{l}\text { Computer } \\
\text { Engineers }\end{array}$} & \multicolumn{3}{|c|}{$\begin{array}{l}\text { Computer } \\
\text { Programm } \\
\text { ers/Applica } \\
\text { tion } \\
\text { Developers }\end{array}$} & \multicolumn{3}{|c|}{$\begin{array}{l}\text { Electronic } \\
\text { and } \\
\text { Electrical } \\
\text { Engineers }\end{array}$} & \multicolumn{2}{|c|}{$\begin{array}{l}\text { Desk } \\
\text { Officers }\end{array}$} & \multicolumn{3}{|c|}{$\begin{array}{l}\text { Content } \\
\text { Developers/ } \\
\text { Innovators } \\
\text { for Changes } \\
\text { and } \\
\text { Upgrading }\end{array}$} & \multicolumn{3}{|c|}{$\begin{array}{l}\text { Facility } \\
\text { managers } \\
\text { like } \\
\text { cleaners, } \\
\text { security } \\
\text { men etc. }\end{array}$} \\
\hline & $\mathrm{R}$ & A dif & $\mathrm{R}$ & A & dif & $\mathrm{R}$ & A & dif & $\mathrm{R}$ & \begin{tabular}{l|l} 
A & dif
\end{tabular} & $\mathrm{R}$ & A & dif & $\mathrm{R}$ & A & dif \\
\hline ABUAD & 2 & $3+1$ & 2 & 2 & 0 & 2 & 2 & 0 & 2 & $8+6$ & 2 & 2 & 0 & 2 & 3 & +1 \\
\hline OAU & 2 & \begin{tabular}{l|l}
$4+2$ \\
\end{tabular} & 4 & 4 & 0 & - & - & 0 & 2 & \begin{tabular}{l|l}
2 & 0 \\
\end{tabular} & 2 & 2 & 0 & 2 & 10 & +8 \\
\hline FUOYE & 2 & $3+1$ & 2 & 4 & +2 & 2 & 2 & 0 & 2 & $3+1$ & 2 & 3 & +1 & 2 & 4 & +2 \\
\hline FUNAAB & 1 & $3+2$ & 1 & 2 & +1 & 1 & 3 & +2 & 2 & $4+2$ & 2 & 3 & +1 & 4 & 6 & +2 \\
\hline RUN & 2 & \begin{tabular}{l|l}
2 & 0
\end{tabular} & 2 & 2 & 0 & 1 & 2 & +1 & 2 & \begin{tabular}{l|l}
2 & 0
\end{tabular} & 2 & 2 & 0 & 2 & 2 & 0 \\
\hline BABCOCK & 1 & \begin{tabular}{l|l}
$3+2$ \\
\end{tabular} & 1 & 2 & +1 & 1 & 2 & +1 & 2 & $3+1$ & 2 & 3 & +1 & 2 & 2 & 0 \\
\hline UNIOSUN & 1 & $6+5$ & 1 & 3 & +2 & 1 & 4 & +3 & 2 & $9+7$ & 5 & & +5 & 4 & 10 & +6 \\
\hline EKSU & 2 & \begin{tabular}{|l|l|}
2 & 0 \\
\end{tabular} & 2 & 3 & +1 & 1 & 2 & +1 & 2 & \begin{tabular}{l|l}
2 & 0
\end{tabular} & 2 & 3 & +1 & 2 & 2 & 0 \\
\hline OOU & 1 & \begin{tabular}{l|l}
$3+2$ \\
\end{tabular} & 2 & 3 & +1 & 1 & 2 & +1 & 2 & \begin{tabular}{l|l}
2 & 0
\end{tabular} & 6 & 5 & -1 & 2 & 2 & 0 \\
\hline
\end{tabular}

Note:

$\mathrm{R}=$ Required number of personnel,

A = Available number of personnel.

dif $=$ Difference

$(+)=$ Level of excess adequacy

$(-)=$ Level of inadequacy

Table 4 shows that the ICT personnel needed for starting online guidance and counselling services in the universities were adequate in all the selected universities. It is concluded that the ICT units in the universities had the needed ICT personnel for the installation and maintenance of OGCS platform.

\section{DISCUSSION}

Given the previous research findings that online counselling services can be a viable supplement to face to face mode of helping university staff and students' clients overcome academic and socio-personal concerns, its establishment in other Nigerian university may be getting more imperative than ever (Adebowale 2013). However the need to assess the available human and material resources required for online guidance and counselling in these institutions is necessary so as to adjudge its reliability, effectiveness and efficiency. Consequently, the first research question posed to appraise the availability and adequacy of facilities for online guidance and counselling in the institutions under study. The result revealed that the facilities required for online guidance and counselling were available with certain degrees in the institutions under study, most of the private universities are favourably disposed in terms of facilities. Four of the universities have adequate supply of facilities while the remaining five have fairly adequate supply. There is no university in the study area that ranked grossly inadequate.

Only one of the federal universities in south west was found to possess adequate facility for online guidance and counselling. This may be a further confirmation of findings reported by Anifowose and Lawal (2013) and Babatope (2010) that physical facilities were grossly inadequate in most Nigerian universities and attributed this to the abysmally poor level of financing and maintenance of the said universities. 
It appears from the study findings that the most readily available facility for online guidance and counselling services in the institutions was internet facility where all the universities perform creditably well. This is also in agreement with the findings of Bamigboye and Agboola (2011). They confirmed that students and staff of University of Ibadan and University of Lagos enjoyed adequate internet connectivity in the libraries, staff offices, hostels, and faculty libraries. Also with the private universities, internet facility, were earlier found to be adequate in Babcock (Oriogu, Ogbuiyi and Ogbuiyi 2014).

It can therefore be concluded that in most of the universities under study, facilities for online guidance and counselling services were only fairly available and accessible, particularly with reference to facilities like audio-visual recorders, counselling data base and online counselling application

The personnel were reported to be available even though the number available was less than the number required and was therefore inadequate. The competence of the available personnel when viewed from the angle of certification and years of experience they had put into the service of the institution may make one to want to say they will be competent, but further discovery revealed that none of the personnel had ever worked, or is currently working on OGCS. This means that the set of counsellors to be used for OGCS must be given training first before they can be co-opted to operate the OGCS platform. This is in agreement with the results of Popoola, Adebowale, Akintomide and Olatomide (2012) that an online counsellor needs to acquire some level of proficiency in communication technologies especially in the areas of handling computers and effective use of the internet. Also he/she must be well equipped with the principles of effective communication, be versed in internet languages and some emotional icons (emoticons) for him/her to be useful for online services work.

Also, the responses given by the directors of ICT revealed that the available personnel in ICT are greater than the needed personnel for implementation of OGCS platform in each of the institutions. The ICT will only need to assign part of their work force for the establishment of OGCS because the personnel were already there at the ICT department. It is only the electrical engineers that are not part of their own work force and also facility manager whose work is more or less an ad hoc one and does not need great certification. In other words, the personnel that are needed from the ICT department are available and are competent for the job.

\section{CONCLUSION}

Based on the results of the analysis, it could be concluded that some facilities and personnel are on ground for the commencement of online counselling programme to resolve the militating challenges for OGCS. The commencement of online counselling will make any willing university to upgrade her lead in the comity of higher institutions in Nigeria that will be making learning support services available to their students.

Realizing that the baseline for hosting online counselling outfit is the existence of the conventional counselling, this could be developed upon as the counsellors could be trained to take up online counselling platform assignments. From the result of this study, it is obvious that there is no university that is not capable of hosting online counselling outfit for as long as they are ready to make provision for all the facilities namely: money, material and manpower enumerated in the study.

\section{RECOMMENDATIONS}

As a result of inherent advantages of online counselling as enumerated in the study, it is hereby recommended that: 
1. All the tertiary institutions in Nigeria should be encouraged to host online guidance and counselling platform in their institutions so as to assist the students who might find it difficult to come face to face with the conventional counsellors. This will go a long way in attending to the challenges of vast majority of students who might be in need of counselling assistance.

2. The use of online counselling services should be given institutional support. This could be done by giving the needful trainings to counsellors from time to time and by encouraging both staff and students of Nigerian universities to have uninhibited access to the online counsellors even before they resume for the semester. In as much as they are registered members of the university, they should have free access to contact their counsellor for the courses they aim to register for etc.

3. More counsellors should be recruited and they must not be saddled with academic and administrative responsibility so that they might be able to face the job of a counsellor without diversion and that the counselling services might be productive and result assuring.

4. Online counselling facilities that are needful for the un-inhibited online counselling platform should be adequately provided, periodically upgraded and routinely serviced and periodically assessed for quality assurance purposes.

\section{References}

Adamu, A. (2017). Student population in Nigerian Open University hits 254,000 February 12, 2017 Premium Times

Adebowale, O. F. (2013). Viability of online guidance and counselling services at Obafemi Awolowo University. Unpublished Ph. D. Thesis of Obafemi Awolowo University. Ile-Ife.

Adebowale, O. F. (2014). Disposition of students to online counselling: The Obafemi Awolowo University, Nigerian experience. International Journal of Education and Development using Information and Communication Technology (IJEDICT), 10(3), 49-74.

Adebowale, O. F. \& Popoola, B. I. (2011). Prospects and challenges of online guidance and counselling services in a Nigerian University. International Journal for the Advancement of Counselling, 33(1), 64-78.

Adebowale, O. F., Popoola, B. I., Obisakin, C. B. \& Aluede, O. (2012). The emerging role of ICT (online counselling) in Nigerian Universities: The Obafemi Awolowo University experience. The Counsellor, 31(1), 25-38.

Anifowose, M. O. \& Lawal, P. O. (2013). State of Physical Facilities in Nigerian Tertiary Educational institutions: A Case Study of the Federal University of Technology, Minna, Niger State, Nigeria. Nigerian Journal of Technological Research, 6 (1)

Arijesuyo, A. E. (2013) Evaluation of counselling and human development programme implementation in southwestern Nigerian universities. International Journal of Innovative Education Research 5(1):1-8, Jan.-Mar., 2017

Babatope, B. A. (2010). Problems of Facilities in South-West Nigerian Universities and the Way Forward. Journal of Education, Administration and Policy Studies 2(2), 39-43.

Bahr, N. \& Pendergast, D. (2007). The Millennial Adolescent. Melbourn Australia: Australian Council for Educational Research (ACER) Press.

Bamigboye, O. B. \& Agboola, E. O. (2011). Availability and Accessibility of Internet Facilities in Nigerian University Libraries: A Case Study of two Federal Universities in South West Nigeria. Library philosophy and Practice.

Retrieved June 8, 2017 From http://digitalcommuns.edu/libprac/547

Campbell, M. A. (2005). Cyber bullying: An Old Problem in a New Guise? Australian Journal of Guidance and Counselling; 15; 68-76.

Campbell, M. A. \& Glasheen, K. J. (2012). The provision of Online Counselling for young people in B. I. Popoola \& O.F. Adebowale (eds) Online Guidance and Counselling, Towards Effectively Applying Technology. 1 - 13.

Dunn, K. (2012). A qualitative investigation into the online counselling relationship: To meet or not to meet, that is the question. Counselling and Psychotherapy Research 12, (4) 316-326 
Federal Republic of Nigeria (1981) National Policy on Education Federal Ministry of Education, (2000). Blue print on guidance and counselling for educational institution in Nigeria

Mallen, M. J., Michael, J., David L. \& Vogel, D.L. (2005). Introduction to the Major Contribution Counselling Psychology and Online Counselling. The Counselling Psychologist, 33(6), 761-775.

Ojo, O. D. (2012) Faceless counselling: trend of technological development in B. I. Popoola, \& O. F. Adebowale (eds). Online Guidance and Counselling, Towards Effectively Applying Technology.

Okobiah, O. C. \& Okorodudu, R. I. (2004). Concepts of Guidance and Counselling. In Okobiah, O. C. \& Okorodudu, R. I.(Eds). Issues, concepts, theories and techniques of guidance and counselling. Benin City: Ethiope Publishing Corporation.

Oriogu C. D., Ogbuiyi, S. U. \& Ogbuiyi, C. D. (2014). Availability and Accessibility of ICT in the provision of information reauhs to undergraduate students in Babcock university Library. Research on Humanity and Social Sciences, 4(14), 29-33

Popoola B. I., Adebowale, O. F., Akintomide, A. G. \& Olatomide O. 0. (2012). Intimacy and Relational Communication in Online Counselling. Online Guidance and Counselling: Toward Effectively Applying Technology. Information Science Reference, Harshey, USA

Sharma, C. (2011). Mobile Predictions Survey. Retrieved on Jan 2, 2012 from https://www.slideshare.net/chetansharma/2012-

mobileindustrypredictionssurve. Mobile IndustryPredictions by Chetan Sharma Consulting.

Suler, J. (2000). Psychotherapy in cyberspace: A 5 dimensional model of online and computer-mediated psychotherapy. Cyber-psychology and behaviour, 3(2), 151-160

Suler, J. (2001). Psychology of Cyberspace - The Online Disinhibition Effect. (Revised 2004).

Suler, J. (2004). The online Disinhibition Effect. The_online_disinhibition_effect Academia.edu Volume 7, Number 3, 2004 Pg 322 - 323

Tenebe, V. A. (2012). National Open University of Nigeria, (Noun). Student Enrollment Hits 180,000. www.noun.edu.ng Retrieved Feb 12, 2017

Umoh, S. H. (2004). The need for guidance and counselling in the Nigerian Educational system. In Idowu, A. (Ed) Guidance and Counselling in education . Ilorin: Indemac Publishers (Nig) Ltd.

University of Zurich. (2013). Psychotherapy via internet as good, if not better than face-to-face consultations. Science Daily, 30 July 2013.

Vossler, A. \& Hanley, T. (2010). Online counselling: Meeting the needs of young people in late-modern societies. In J. Leaman \& M. Woersching (eds.), Youth in Contemporary Europe. London: Routledge.

Yusuf, M. O. \& Balogun, M. R. (2011). Student-Teachers' Competence and Attitude towards Information and Communication Technology: A Case Study in a Nigerian University. Journal of Contemporary Educational Technology, 2(1), 18-36 18 